\title{
EFFECT OF PLANTING TIME AND STORAGE METHODS ON GRAIN WEEVILS, SITOPHILUS SPP (COLEOPTERA: CURCULIONIDAE) INFESTING WHEAT GRAINS
}

\author{
M.B. Attia, A.I. Farag, Saadeia M. Saed and Nehal O. Swelam \\ Department of Economic Entomology and Agriculture Zoology, Faculty of Agriculture, \\ Menoufia University
}

Received: Jan. 22, 2017

Accepted: Feb. 19, 2017

\begin{abstract}
This research was conducted at special farms in Shebin Elkom locality to study the effect of planting wheat at five times (Oct. 30, Nov. 10, Nov. 16, Nov. 20, Nov. 26, 2012 ) and harvested at four times (Apr. 4, Apr. 19, Apr. 22, Apr. 29, 2013) on the infestation of the grain weevils, Sitophilus spp, (Coleoptera: Curculionidae, along one year of storing at five tools (Metal silos, Mud silos, Polyethylene bags, Jute bags, Plastic fiber bags). Wheat grain samples $(100 \mathrm{~g})$ of each store model of stored grains were examined by eye and with the aid of handle lens $(6 x)$ to calculate the average number of weevil insects per $100 \mathrm{~g}$. Treatments were replicated three times. Statistical analysis of the obtained results indicated that there were significant differences in the annual weevil numbers among the planting times, the best planting time is 20 November because it has the lowest infestation numbers of weevil insects recording 4103 weevil / $100 \mathrm{~g}$ wheat grains, while the highest weevil numbers was recorded with the planting time 10 November giving 15796 weevil / $100 \mathrm{~g}$ wheat grains. Regarding to the storing tools, results indicated that there were significant differences in the annual weevil numbers between plastic fiber bags and all other tools recording the lowest numbers of grain weevil insects 5495 individual / $100 \mathrm{~g}$. The highest annual numbers of grain weevils recorded in mud silos and polyethylene bags (10082- 10584 weevil / 100 g) respectively. From the obtained results it could be concluded that the suitable planting time to cultivate wheat is 20 November which resulted the lowest numbers of weevil insects, as well as the suitable tool for wheat grain storing is plastic fiber bags in comparison with other tools.
\end{abstract}

Key words: stored grains; wheat weevil, storing methods, wheat pests, protection

\section{INTRODUCTION}

Losses of wheat due to inadequate storage and other post-harvest factors at the farm, village and commercial levels of up to 4 percent have been observed (McFarlane, 1989; Abdullahi and Haile, 1991).

Deterioration of stored grain is influenced by physical factors (temperature, humidity), biological factors (micro flora, arthropod, and vertebrate) and technical factors (storage conditions, methods and duration) (Tyler and Boxall, 1984). Storage conditions determine the safe storage period for any grain (Cox and Collins 2002).

The purpose of this study aimed to evaluate the effect of some agricultural methods i.e. planting time, harvesting time, method of storage on grain weevils, Sitophilus spp, infestation to the stored wheat grains to recognize the suitable time to plant wheat, to harvest and the best storage method.

\section{MATERIALS AND METHODS}

This work was carried out at special farms in Shebin Elkom locality during the period from November, 2012 till June, 2014.

\section{1- Insects under research:}

The most known species of stored grain insects and investigated in this research are the grain weevils, Sitophilus granarius (L.), and S. oryzae (L.), (Coleoptera: Curculionidae). 


\section{2- Wheat variety:}

Wheat grains (Triticum aestivum) variety Sakha 93, were dried well with solar heat for three days, and covered all the night and at morning till the sun rises.

\section{3-Tested techniques:}

Five methods were tested for storing wheat grain under laboratory conditions these methods are metal silos, mud silos, polyethylene bags, jute bags and plastic fiber bags which were prepared and manually designed for all experiments. Each method was sampled five times and organized randomly with cultivated and harvest dates.

\section{3-1- Metal silos:}

Metal cans were prepared like metal silos with capacity of $10 \mathrm{~kg}$ of wheat grains and were covered with metal covers.

\section{3-2- Mud silos:}

Mud silos were made of clay soils were similar to those farmers had early used, with capacity of $10 \mathrm{~kg}$ of wheat grains.

\section{3-3- Polyethylene bags:}

These bags were made of polyethylene and their capacity was $10 \mathrm{~kg}$ of wheat grains.

\section{3-4- Jute bags:}

These bags are naturally material and made of jute fibers where its pores allow both air and humidity to be merged with the atmosphere around the bag and its capacity was $10 \mathrm{~kg}$ of wheat grains.

\section{3-5- Plastic fiber bags:}

These bags had pores allowing air and humidity to be merged with the atmosphere around the bag and its capacity was $10 \mathrm{~kg}$ of wheat grains.

\section{4- Sampling and inspection: \\ Sampling:}

Five planting dates of wheat were conducted at private farms in Shebin Elkom locality (Oct. 30, Nov. 10, Nov. 16, Nov. 20,
Nov. 26, 2014 ) and harvested at four times ( Apr. 4, Apr. 19, Apr. 22, Apr. 29, 2015).

The obtained grains were stored for 12 months in the five miniature model of silos (Metal silos, Mud silos, Polyethylene bags, Jute bags, Plastic fiber bags) as previous described and replicated three times. Experiments were conducted for two seasons along two successive years to confirm the results.

Monthly three samples (100 g / replicate) were taken and examined for insect infestation.

\section{Determination of grain moisture content:}

Grain moisture content was determined by drying $100 \mathrm{~g}$ grains in a ventilated electric oven adjusted at $70^{\circ} \mathrm{C}$ for $48 \mathrm{~h}$.

The samples were reweighted using an electrical balance to calculate the moisture percentage according to the following formula:

Moisture content $\%=$

$$
\frac{\text { weight of wet grains-weight of dry grains }}{\text { weight of wt grains }} \times 100
$$

\section{Insect infestation:}

Samples of each model of stored grains were externally examined by eye and with the aid of handle lens $(6 \mathrm{x})$ to determine the visible infested grains. The externally infested grains were counted and excluded from the samples to calculate the degree of infestation.

\section{5- Statistical analysis of the data:}

Decrease percentages in laid eggs were corrected for natural percentages according to (Abbott, 1925) equation. Number of laid eggs / female, hatchability percentage, number of emerged adults, and weight loss $\%$ of wheat grains were calculated. Collected data were subjected to statistical analysis of variance (ANOVA) at $5 \%$ probability, and the measurements were separated using Duncan's Multiple Range 
Test (DMRT) through CoStat software program (Version 6.400). CoStat version 6.400 Copyright (c) 1998-2008 Cohort Software. 798 Lighthouse Ave. PMB 320, Monterey, CA, 93940, USA.

\section{RESULTS AND DISCUSSION}

1- Effect of storing methods on the infestation of wheat weevil insects along storage period from June 2013 to May 2014:

The obtained results in Table (1) show the effect of planting time (30 October, 2012) on monthly average numbers of weevil insects per 100 gram of wheat grains stored in five storing tools.

Statistical analysis of the data (Table 1) indicated that there are significant differences in weevil numbers among examination months (Jun. to May), where there are significant differences in total weevil numbers between Jun. to Nov. and all other months, while there are no significant differences between (Jun. to Nov.) recording the least numbers (0-13 weevil / $100 \mathrm{~g}$ grains). The highest infestation numbers were in the last month of storing giving (2470 weevil/ $100 \mathrm{~g}$ ).

Regarding to the storing tools, results in Table (1) indicated that there are significant differences in total weevil numbers between Mud silos, Jute bags and other tools. Polyethylene bags and Metal silos recorded the least numbers of grain weevils 252 and 330 weevil / $100 \mathrm{~g}$, respectively without significant differences.

Table (1): Effect of storing methods on the infestation of grain weevils, Sitophilus spp along storage period in the wheat planted in Oct. 30 from June 2013 to May 2014.

\begin{tabular}{|c|c|c|c|c|c|c|}
\hline \multirow{3}{*}{$\begin{array}{l}\text { Date of } \\
\text { storage }\end{array}$} & \multicolumn{5}{|c|}{ Storing methods } & \multirow{3}{*}{ Total } \\
\hline & \multicolumn{5}{|c|}{ Average number of weevil insects per $100 \mathrm{~g}$} & \\
\hline & $\begin{array}{l}\text { Mud } \\
\text { silos }\end{array}$ & $\begin{array}{l}\text { Metal } \\
\text { silos }\end{array}$ & $\begin{array}{l}\text { Jute } \\
\text { bags }\end{array}$ & $\begin{array}{c}\text { Polyethylene } \\
\text { bags }\end{array}$ & $\begin{array}{c}\text { Plastic } \\
\text { fiber bags }\end{array}$ & \\
\hline Jun., $1^{\text {st }}$ & 0 & 0 & 0 & 0 & 0 & $0 \mathrm{f}$ \\
\hline Jul., $1^{\text {st }}$ & 0 & 0 & 0 & 0 & 0 & $0 \mathrm{f}$ \\
\hline Aug., $1^{\text {st }}$ & 0 & 0 & 0 & 0 & 0 & $0 \mathrm{f}$ \\
\hline Sept., $1^{\text {st }}$ & 0 & 0 & 0 & 0 & 0 & $0 f$ \\
\hline Oct., $1^{\text {st }}$ & 0 & 0 & 0 & 0 & 0 & $0 \mathrm{f}$ \\
\hline Nov., $1^{\text {st }}$ & 1 & 0 & 11 & 1 & 0 & $13 f$ \\
\hline Dec., $1^{\text {st }}$ & 460 & 50 & 60 & 1 & 0 & $571 \mathrm{~d}$ \\
\hline Jan., $1^{\text {st }}$ & 40 & 10 & 80 & 0 & 0 & $130 \mathrm{f}$ \\
\hline Feb., $1^{\text {st }}$ & 10 & 50 & 180 & 0 & 60 & $300 \mathrm{e}$ \\
\hline Mar., $1^{\text {st }}$ & 420 & 120 & 430 & 80 & 200 & $1250 \mathrm{c}$ \\
\hline Apr., $1^{\text {st }}$ & 500 & 30 & 530 & 60 & 320 & $1440 \mathrm{~b}$ \\
\hline May, $1^{\text {st }}$ & 920 & 70 & 1040 & 110 & 330 & $2470 \mathrm{a}$ \\
\hline Total & $2351 \mathrm{~A}$ & $330 \mathrm{C}$ & $2331 A$ & $252 \mathrm{C}$ & $910 \mathrm{~B}$ & LSD $5 \%$ \\
\hline LSD 5\% & & & 263 & & & 155.7 \\
\hline
\end{tabular}

The different letters in the row or the column means significant differences at $5 \%$ level 
Attia, et al.,

The obtained results in Table (2) show the effect of planting time (10 November, 2012) on monthly average numbers of weevil insects per 100 gram of wheat grains stored in five storing tools.

Statistical analysis of the data (Table 2) indicated that there are significant differences in weevil numbers among examined months (Jun. to May), where there are significant differences in total weevil numbers between Jun. to Oct. and all other months, while there are no significant differences between (Jun. to Oct.) recording the lowest numbers (0 weevil / $100 \mathrm{~g}$ grains). The highest infestation numbers were registered in the last two months of storing (Apr. and May) giving (3300 - 3080 weevil/ $100 \mathrm{~g}$ ) respectively.

Regarding to the storing tools, results in Table (2) indicated that there are significant differences in weevil numbers between Mud silos, Jute bags and other tools and between Polyethylene bags and Metal silos. Plastic fiber bags recorded the lowest numbers of grain weevils 885 weevil / $100 \mathrm{~g}$.

The obtained results in Table (3) show the effect of planting time (16 November, 2012) on monthly average numbers of weevil insects per 100 gram of wheat grains stored in five storing tools.

Statistical analysis of the data (Table 3) indicated that there are significant differences in weevil numbers among examination months (Jun. to May), where there were significant differences in weevil numbers between Jun. to Nov. and all other months, while there are no significant differences between (Jun. to Nov.) recording the least numbers (0-139 weevil / $100 \mathrm{~g}$ grains). The highest infestation numbers were in the last month of storing giving (3580 weevil/ $100 \mathrm{~g}$ ).

Table (2): Effect of storing methods on the infestation of grain weevils, Sitophilus spp along storage period in the wheat planted in Nov. 10 from June 2013 to May 2014

\begin{tabular}{|c|c|c|c|c|c|c|}
\hline \multirow{3}{*}{$\begin{array}{l}\text { Date of } \\
\text { storage }\end{array}$} & \multicolumn{5}{|c|}{ Storing methods } & \multirow{3}{*}{ Total } \\
\hline & \multicolumn{5}{|c|}{ Average number of weevil insects per $100 \mathrm{~g}$} & \\
\hline & $\begin{array}{l}\text { Mud } \\
\text { silos }\end{array}$ & $\begin{array}{l}\text { Metal } \\
\text { silos }\end{array}$ & $\begin{array}{l}\text { jute } \\
\text { bags }\end{array}$ & $\begin{array}{c}\text { Polyethylene } \\
\text { bags }\end{array}$ & $\begin{array}{c}\text { Plastic } \\
\text { fiber bags }\end{array}$ & \\
\hline Jun., $1^{\text {st }}$ & 0 & 0 & 0 & 0 & 0 & $0 \mathrm{f}$ \\
\hline Jul., $1^{\text {st }}$ & 0 & 0 & 0 & 0 & 0 & $0 \mathrm{f}$ \\
\hline Aug., $1^{\text {st }}$ & 0 & 0 & 0 & 0 & 0 & $0 \mathrm{f}$ \\
\hline Sept., $1^{\text {st }}$ & 0 & 0 & 0 & 0 & 0 & $0 \mathrm{f}$ \\
\hline Oct., $1^{\text {st }}$ & 0 & 0 & 0 & 0 & 0 & $0 \mathrm{f}$ \\
\hline Nov., $1^{\text {st }}$ & 1 & 500 & 100 & 380 & 25 & $1006 \mathrm{e}$ \\
\hline Dec., $1^{\text {st }}$ & 460 & 900 & 50 & 960 & 10 & $2380 \mathrm{~b}$ \\
\hline Jan., $1^{\text {st }}$ & 40 & 920 & 80 & 250 & 40 & $1330 \mathrm{~d}$ \\
\hline Feb., $1^{\text {st }}$ & 10 & 820 & 200 & 900 & 110 & $2040 \mathrm{c}$ \\
\hline Mar., $1^{\text {st }}$ & 420 & 800 & 270 & 1040 & 130 & $2660 \mathrm{~b}$ \\
\hline Apr., $1^{\text {st }}$ & 500 & 840 & 660 & 1050 & 250 & $3300 \mathrm{a}$ \\
\hline May, $1^{\text {st }}$ & 920 & 580 & 510 & 750 & 320 & $3080 \mathrm{a}$ \\
\hline Total & 2351B & $5360 \mathrm{~A}$ & $1870 \mathrm{~B}$ & $5330 \mathrm{~A}$ & $885 \mathrm{C}$ & LSD 5\% \\
\hline LSD 5\% & \multicolumn{5}{|c|}{672.6} & 296.7 \\
\hline
\end{tabular}

The different letters in the row or the column means significant differences at $5 \%$ level 
Table (3): Effect of storing methods on the infestation of grain weevils, Sitophilus spp along storage period in the wheat planted in Nov. 16 from June 2013 to May 2014 .

\begin{tabular}{|c|c|c|c|c|c|c|}
\hline \multirow{3}{*}{$\begin{array}{l}\text { Date of } \\
\text { storage }\end{array}$} & \multicolumn{5}{|c|}{ Storing methods } & \multirow{3}{*}{ Total } \\
\hline & \multicolumn{5}{|c|}{ Average number of weevil insects per $100 \mathrm{~g}$} & \\
\hline & $\begin{array}{l}\text { Mud } \\
\text { silos }\end{array}$ & $\begin{array}{l}\text { Metal } \\
\text { silos }\end{array}$ & $\begin{array}{l}\text { jute } \\
\text { bags }\end{array}$ & $\begin{array}{c}\text { Polyethylene } \\
\text { bags }\end{array}$ & $\begin{array}{c}\text { Plastic } \\
\text { fiber bags }\end{array}$ & \\
\hline Jun., $1^{\text {st }}$ & 0 & 0 & 0 & 0 & 0 & $0 f$ \\
\hline Jul., $1^{\text {st }}$ & 0 & 0 & 0 & 0 & 0 & $0 f$ \\
\hline Aug., $1^{\text {st }}$ & 0 & 0 & 0 & 0 & 0 & $0 \mathrm{f}$ \\
\hline Sept., $1^{\text {st }}$ & 0 & 0 & 0 & 0 & 0 & $0 \mathrm{f}$ \\
\hline Oct., $1^{\text {st }}$ & 0 & 0 & 0 & 0 & 0 & $0 \mathrm{f}$ \\
\hline Nov., $1^{\text {st }}$ & 70 & 3 & 6 & 30 & 30 & $139 \mathrm{f}$ \\
\hline Dec., $1^{\text {st }}$ & 220 & 60 & 30 & 330 & 50 & $690 \mathrm{e}$ \\
\hline Jan., $1^{\text {st }}$ & 290 & 100 & 190 & 140 & 190 & $910 \mathrm{de}$ \\
\hline Feb., $1^{\text {st }}$ & 200 & 100 & 220 & 290 & 160 & $970 d$ \\
\hline Mar., $1^{\text {st }}$ & 250 & 150 & 490 & 430 & 210 & $1530 \mathrm{c}$ \\
\hline Apr., $1^{\text {st }}$ & 220 & 90 & 640 & 550 & 510 & $2010 \mathrm{~b}$ \\
\hline May, $1^{\text {st }}$ & 1180 & 80 & 560 & 700 & 1060 & 3580 a \\
\hline Total & $2430 \mathrm{~A}$ & $583 \mathrm{~B}$ & $2136 \mathrm{~A}$ & $2470 \mathrm{~A}$ & $2210 \mathrm{~A}$ & LSD 5\% \\
\hline LSD $5 \%$ & & & 368 & & & 222 \\
\hline
\end{tabular}

The different letters in the row or the column means significant differences at $5 \%$ level

Regarding to the storing tools, results in Table (3) indicated that there are significant differences in total weevil numbers between Metal silos, and all other tools recorded the lowest numbers of grain weevils 583 weevil / $100 \mathrm{~g}$.

The obtained results in Table (4) show the effect of planting time (20 November, 2012) on monthly average numbers of weevil insects per 100 gram of wheat grains stored in five storing tools.

Statistical analysis of the data (Table 4) indicated that there are significant differences in weevil numbers among examination months (Jun. to May), where there are significant differences in total weevil numbers between Jun. to Nov. and all other months, while there were no significant differences between (Jun. to Nov.) recording the least numbers (0- 12 weevil / $100 \mathrm{~g}$ grains). The highest infestation numbers were in the last month of storing giving (1850 weevil/ $100 \mathrm{~g}$ ).

Regarding to the storing tools, results in Table (4) indicated that there are significant differences in total weevil numbers between Metal silos, Plastic fiber bags and all other tools recorded the lowest numbers of grain weevils (251- 140 weevil / $100 \mathrm{~g})$ respectively. The highest numbers of grain weevils were recorded in Polyethylene bags $(1630$ weevil / $100 \mathrm{~g})$ there are significant differences between Polyethylene bags and all other methods. 
Attia, et al.,

Table (4): Effect of storing methods on the infestation of grain weevils, Sitophilus spp along storage period in the wheat planted in Nov. 20 from June 2013 to May 2014.

\begin{tabular}{|c|c|c|c|c|c|c|}
\hline \multirow{3}{*}{$\begin{array}{l}\text { Date of } \\
\text { storage }\end{array}$} & \multicolumn{5}{|c|}{ Storing methods } & \multirow{3}{*}{ Total } \\
\hline & \multicolumn{5}{|c|}{ Average number of weevil insects per $100 \mathrm{~g}$} & \\
\hline & $\begin{array}{l}\text { Mud } \\
\text { silos }\end{array}$ & $\begin{array}{l}\text { Metal } \\
\text { silos }\end{array}$ & $\begin{array}{l}\text { jute } \\
\text { bags }\end{array}$ & $\begin{array}{c}\text { Polyethylene } \\
\text { bags }\end{array}$ & $\begin{array}{c}\text { Plastic } \\
\text { fiber bags }\end{array}$ & \\
\hline Jun., $1^{\text {st }}$ & 0 & 0 & 0 & 0 & 0 & $0 \mathrm{f}$ \\
\hline Jul., $^{\text {st }}$ & 0 & 0 & 0 & 0 & 0 & $0 \mathrm{f}$ \\
\hline Aug., $1^{\text {st }}$ & 0 & 0 & 0 & 0 & 0 & $0 \mathrm{f}$ \\
\hline Sept., ${ }^{\text {st }}$ & 0 & 0 & 0 & 0 & 0 & $0 \mathrm{f}$ \\
\hline Oct., $1^{\text {st }}$ & 0 & 0 & 0 & 0 & 0 & $0 \mathrm{f}$ \\
\hline Nov., $1^{\text {st }}$ & 10 & 1 & 1 & 0 & 0 & $12 \mathrm{f}$ \\
\hline Dec., $1^{\text {st }}$ & 10 & 20 & 1 & 10 & 0 & 41 ef \\
\hline Jan., $1^{\text {st }}$ & 110 & 10 & 10 & 0 & 0 & 130 de \\
\hline Feb., $1^{\text {st }}$ & 70 & 20 & 30 & 100 & 0 & $220 d$ \\
\hline Mar., $1^{\text {st }}$ & 40 & 70 & 190 & 200 & 20 & $520 \mathrm{c}$ \\
\hline Apr., $1^{\text {st }}$ & 280 & 40 & 410 & 540 & 60 & $1330 \mathrm{~b}$ \\
\hline May, $1^{\text {st }}$ & 560 & 90 & 360 & 780 & 60 & $1850 \mathrm{a}$ \\
\hline Total & $1080 \mathrm{~B}$ & $251 \mathrm{C}$ & $1002 \mathrm{~B}$ & $1630 \mathrm{~A}$ & $140 \mathrm{C}$ & LSD 5\% \\
\hline LSD 5\% & & & 158 & & & 113.3 \\
\hline
\end{tabular}

The different letters in the row or the column means significant differences at $5 \%$ level

The obtained results in Table (5) show the effect of planting time (26 November, 2012) on monthly average numbers of weevil insects per 100 gram of wheat grains stored in five storing tools.

Statistical analysis of the data (Table 5) indicated that there are significant differences in weevil numbers among examination months (Jun. to May), where there were significant differences in total weevil numbers between Jun. to Oct. and all other months, while there are no significant differences between (Jun. to Oct.) recording the least numbers ( 0 weevil / $100 \mathrm{~g}$ grains). The highest infestation numbers were in the last month of storing giving (2680 weevil/ $100 \mathrm{~g}$ ).

Regarding to the storing tools, results in Table (5) indicated that there are significant differences in total weevil numbers between Metal silos and all other tools recorded the lowest numbers of grain weevils (780 weevil / $100 \mathrm{~g}$ ). The highest numbers of grain weevils were recorded in Mud silos (1870 weevil / $100 \mathrm{~g}$ ) and there were significant differences between Mud silos and all other methods.

The obtained results in Table (6) show the effect of planting time and the storing methods on the annual average numbers of weevil insects per 100 gram of wheat grains.

Statistical analysis of the data (Table 6) indicated that there was significant differences in the annual weevil numbers among the planting times, the best planting time is 20 November because it has the lowest infestation numbers of weevil insects recording 4103 weevil / $100 \mathrm{~g}$ wheat grains, while the highest weevil numbers was recorded with the planting time 10 November giving 15796 weevil / 100 g wheat grains. 
Table (5): Effect of storing methods on the infestation of grain weevils, Sitophilus spp along storage period in the wheat planted in Nov. 26 from June 2013 to May 2014.

\begin{tabular}{|c|c|c|c|c|c|c|}
\hline \multirow{3}{*}{$\begin{array}{l}\text { Date of } \\
\text { storage }\end{array}$} & \multicolumn{5}{|c|}{ Storing methods } & \multirow{3}{*}{ Total } \\
\hline & \multicolumn{5}{|c|}{ Average number of weevil insects per $100 \mathrm{~g}$} & \\
\hline & $\begin{array}{l}\text { Mud } \\
\text { silos }\end{array}$ & $\begin{array}{l}\text { Metal } \\
\text { silos }\end{array}$ & $\begin{array}{l}\text { jute } \\
\text { bags }\end{array}$ & $\begin{array}{l}\text { Polyethylene } \\
\text { bags }\end{array}$ & $\begin{array}{l}\text { Plastic } \\
\text { fiber bags }\end{array}$ & \\
\hline Jun., $1^{\text {st }}$ & 0 & 0 & 0 & 0 & 0 & $0 \mathrm{~g}$ \\
\hline Jul., $^{\text {st }}$ & 0 & 0 & 0 & 0 & 0 & $0 \mathrm{~g}$ \\
\hline Aug., $1^{\text {st }}$ & 0 & 0 & 0 & 0 & 0 & $0 \mathrm{~g}$ \\
\hline Sept., $1^{\text {st }}$ & 0 & 0 & 0 & 0 & 0 & $0 \mathrm{~g}$ \\
\hline Oct., $1^{\text {st }}$ & 0 & 0 & 0 & 0 & 0 & $0 \mathrm{~g}$ \\
\hline Nov., $1^{\text {st }}$ & 80 & 0 & 0 & 0 & 0 & $80 \mathrm{fg}$ \\
\hline Dec., $1^{\text {st }}$ & 140 & 10 & 0 & 20 & 30 & 200 ef \\
\hline Jan., $1^{\text {st }}$ & 130 & 70 & 20 & 2 & 20 & $242 \mathrm{e}$ \\
\hline Feb., $1^{\text {st }}$ & 140 & 130 & 130 & 10 & 90 & $500 d$ \\
\hline Mar., $1^{\text {st }}$ & 130 & 160 & 90 & 30 & 320 & $730 \mathrm{c}$ \\
\hline Apr., $1^{\text {st }}$ & 330 & 280 & 410 & 310 & 220 & $1550 \mathrm{~b}$ \\
\hline May, $1^{\text {st }}$ & 920 & 130 & 430 & 530 & 670 & $2680 \mathrm{a}$ \\
\hline Total & $1870 \mathrm{~A}$ & $780 \mathrm{D}$ & $1080 \mathrm{C}$ & $902 \mathrm{CD}$ & $1350 \mathrm{~B}$ & \multirow{2}{*}{$\begin{array}{c}\text { LSD } 5 \% \\
156\end{array}$} \\
\hline LSD $5 \%$ & \multicolumn{5}{|c|}{226.9} & \\
\hline
\end{tabular}

The different letters in the row or the column means significant differences at $5 \%$ level

Table (6): Aver. annual no. of weevil insects / $100 \mathrm{~g}$ wheat stored by five methods for one year.

\begin{tabular}{|c|c|c|c|c|c|c|}
\hline \multirow{3}{*}{$\begin{array}{l}\text { Date of } \\
\text { planting }\end{array}$} & \multicolumn{5}{|c|}{ Storing methods } & \multirow{3}{*}{ Total } \\
\hline & \multicolumn{5}{|c|}{$\begin{array}{l}\text { Average annual numbers of weevil insects for } 100 \mathrm{~g} \\
\text { wheat stored by } 5 \text { methods }\end{array}$} & \\
\hline & $\begin{array}{l}\text { Mud } \\
\text { silos }\end{array}$ & $\begin{array}{l}\text { Metal } \\
\text { silos }\end{array}$ & $\begin{array}{c}\text { jute } \\
\text { bags }\end{array}$ & $\begin{array}{c}\text { Polyethylene } \\
\text { bags }\end{array}$ & $\begin{array}{c}\text { Plastic } \\
\text { fiber bags }\end{array}$ & \\
\hline Oct. 30 & 2351 & 330 & 2331 & 252 & 910 & $6174 \mathrm{c}$ \\
\hline Nov. 10 & 2351 & 5360 & 1870 & 5330 & 885 & $15796 a$ \\
\hline Nov.16 & 2430 & 583 & 2136 & 2470 & 2210 & $9829 \mathrm{~b}$ \\
\hline Nov.20 & 1080 & 251 & 1002 & 1630 & 140 & $4103 d$ \\
\hline Nov.26 & 1870 & 780 & 1080 & 902 & 1350 & $5982 \mathrm{c}$ \\
\hline $\begin{array}{l}\text { Grand } \\
\text { Total }\end{array}$ & $10082 \mathrm{~A}$ & 7304 B & 8419 B & $10584 \mathrm{~A}$ & 5495 C & \multirow{2}{*}{$\begin{array}{l}\text { LSD } 5 \% \\
1699.6\end{array}$} \\
\hline LSD 5\% & \multicolumn{5}{|c|}{1256.5} & \\
\hline
\end{tabular}

The different letters in the row or the column means significant differences at $5 \%$ level

Regarding to the storing tools, results in Table (6) indicated that there are significant differences in the annual weevil numbers between Plastic fiber bags and all other tools recording the lowest numbers of grain weevils 5495 weevil / $100 \mathrm{~g}$. The highest annual numbers of grain weevils recorded in 
Mud silos and Polyethylene bags (1008210584 weevil / $100 \mathrm{~g}$ ) respectively.

From the obtained results it could be concluded that the suitable planting time to cultivate wheat is 20 November which resulted the lowest numbers of weevil insects, as well as the suitable tool for wheat grain storing is plastic fiber bags in comparison with other tools.

These results are in harmony with those of Bala et al. (1993) who studied the storage of Paddy in three different types of traditional storage systems, Driscoll et al. (2000) test a Prediction program for insect populations in grain storage, Hagstrum (2000) used five sampling methods to measure insect distribution and abundance in bins storing wheat. Villers et al. (2006) studied the safe storage of grain in the tropics: A comparison of hermetic storage in flexible silos versus rigid metal or concrete silos, Fourar et al. (2011) studied the prediction and the deterioration risks in unsafe storage conditions in relation to relative humidity level, infestation by Sitophilus oryzae (L.), and wheat variety. Chigoverah and Mvumi (2016) who studied the efficacy of metal silos and hermetic bags against stored-maize insect pests under simulated smallholder farmer conditions.

\section{REFERENCES}

Abbott, W.S. (1925) . A method of computing the effectiveness of an insecticide. J. Econ. Entomol.; 18 : 265-267.

Abdullahi, A. and A. Haile (1991). Research on the control of insect and rodent pests of wheat in Ethiopia. In Wheat research in Ethiopia: a historical perspective. Addis Ababa, IAR/CIMMYT.

Bala, B.K., M.A. Zaman, B.K. Biswas and M.I Hussain (1993). Studies on storage of Paddy in three different types of traditional storage systems. Agricultural Engineering journal, 2(3): 12 1-137

Chigoverah, A.A. and B.M. Mvumi (2016). Efficacy of metal silos and hermetic bags against stored-maize insect pests under simulated smallholder farmer conditions. Journal of Stored Products Research 69: 179-189

CoStat version 6.400 Copyright (c) 19982008 Cohort Software. 798 Lighthouse Ave. PMB 320, Monterey, CA, 93940, USA

Cox, P.D. and L.E. Collins (2002). Review: Factors affecting the behavior of beetle pests in stored grain, with particular reference to the development of lures. Journal of Stored Products Research 38: 95-115.

Driscoll, R., B.C. Longstaff and S. Beckett (2000). Prediction of insect populations in grain storage. Journal of Stored Products Research 36: 131-151

Fourar-Belaifa, R., F. Fleurat-Lessard and Z. Bouznad (2011). A systemic approach to qualitative changes in the stored-wheat ecosystem: Prediction of deterioration risks in unsafe storage conditions in relation to relative humidity level, infestation by Sitophilus oryzae (L.), and wheat variety. Journal of Stored Products Research 47: 48-61

Hagstrum, D. W. (2000). Using five sampling methods to measure insect distribution and abundance in bins storing wheat. Journal of Stored Products Research 36: 253-262

McFarlane, J.A. (1989). Guidelines for pest management research to reduce stored food losses caused by insects and mites. Overseas Development and Natural Resources Institute Bulletin No. 22. Chatham, Kent, UK.

Tyler, P.S. and R.A. Boxall (1984). Postharvest loss reduction programmes: a decade of activities: what consequences? Trop. Stored Prod. Info., 23: 13-28.

Villers, Ph., T. Bruin and Sh. Navarro (2006). Safe storage of grain in the tropics: A comparison of hermetic storage in flexible silos versus rigid metal or concrete silos. Linx Publishing LLC 1(3): 1-8. 
تأثير ميعاد الزراعة لنباتات القمح وطرق تخزين الحبوب على الاصابة بحشرات السوس

مكرم باسيلي عطية ، علي إبراهيم فرج ، سعدية محمد سعيد ، نهال أمية سويلم

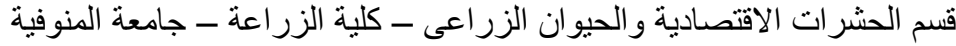

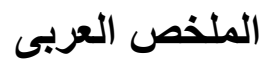

تم اجراء هذا البحث بمزارع خاصة بمنطقة شبين الكوم محافظة المنوفية خلال الموسم الثتوى لعام 2012

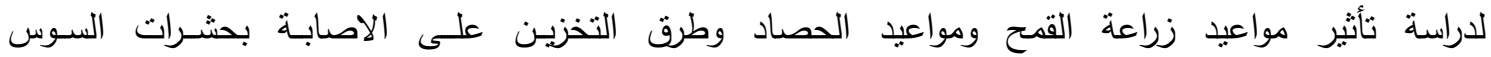
وذللك على مدى عام كامل. حيث تم تخزين حبوب القمح Sitophilus spp, (Coleoptera: Curculionidae) فى خمسة عبوات مختلفة وهى: عبوات من الصفيح - عبوات من الطين (الفخار) - أكياس من البولى ايثيلين أكياس من الجوت - أكياس من الالياف البلاستيكية ونم اخذ عينات شهرية وفحصها للاصابة بحشرات السوس

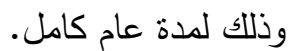
أظهر التحليل الاحصائى للنتائج ان هناك فروقا معنوية فى التعداد السنوى لحشرات السوس بين مواعيد الزراعة المختلفة وكان أنسب ميعاد للزراعة هو 20 نوفمبر معطيا اقل عدد من السوس 4103 سوسة / 100 جرام حبوب / السنة ، بينما كان اكبر تعداد لحشرات السوس فى معاملة الزراعة 10 نوفمبر معطيا 15796 سوسة / 100 جرام حبوب / السنة. كما أظهر التحليل الاحصائى للنتائج ان هناك فروقا معنوية فى التعداد السنوى لحشرات السوس بين وسائل

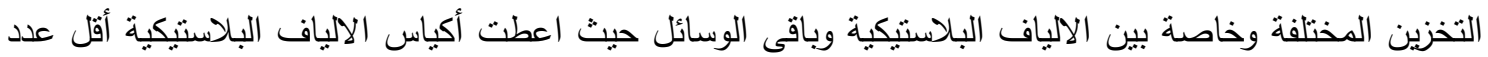
من حشرات السوس 5495 سوسة / 100 جرام حبوب / السنة بينما تراوحت الاعداد السنوية لحشرات السوس بين

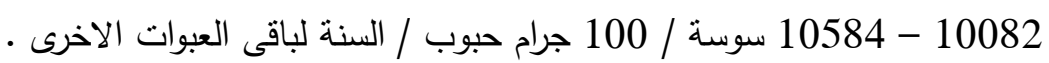

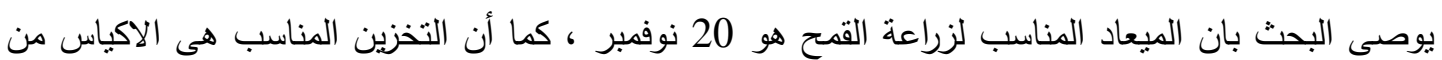
الالياف البلاستيكية حيث قلت اعداد الحشرات معنويا مقارنة بباقى المعاملات. 